
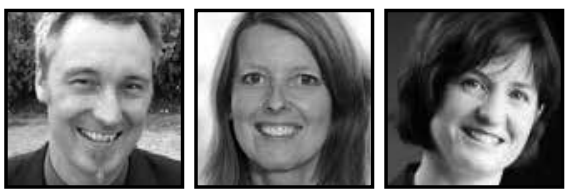

\title{
Teacher Educator Professional Development as Reflexive Inquiry
}

\author{
Leyton Schnellert, Pamela Richardson, and Sabre Cherkowski \\ University of British Columbia
}

\section{ABSTRACT}

Professional development for teacher educators must recognize and account for how aspects of our pedagogies often run counter to institutional, managerial, and bureaucratic demands. We need professional development that nurtures our minds, hearts, and spirits, and that is congruent with our values. In this paper, three teacher educators who co-teach an intensive, interdisciplinary, inquiry-based semester in a secondary teacher education program, explore how collaborative approaches to narrative forms of inquiry and reflexive analysis supported them to enact their learning, as well as helped them to surface the situated, complex, and emergent aspects of their own-as well as their students'_-identities.

\section{Introduction}

\footnotetext{
n this paper, we three teacher educators, all at varied stages of our pre-tenure journey, share a collaborative self-study based in writing about tensions in our work. Through attending to, sharing, and supporting one another via conversations and writing, we identified "telling moments," wrote together, and responded to one another's writing. Consequently, we created and sustained a needed container for sharing our emotions and vulnerabilities, while gaining new perspectives and considering new questions with regards to our experiences.
} 
As we move towards collaborative, interdisciplinary, critical, and inquiry-oriented teacher education programs, and K-12 pedagogy, there is a gap in understanding the professional development of teacher educators in relation to this context. Teacher educators must negotiate and co-create similarly meaningful points of reference for our learning and development within which we reflect on and extend our understandings. What's more, professional development for teacher educators must recognize and account for how aspects of our pedagogies often run counter to institutional, managerial, and bureaucratic demands. We need professional development that nurtures our minds, hearts, and spirits, and that is congruent with our values. We seek to better align our practice with our scholarship by exploring how we embody the theoretical and pedagogic frames through which we invite our teacher candidates to learn.

\section{Arriving at the Focus and Purpose of This Research}

The purpose of this self-study was to explore our experiences with the process of nurturing critical reflection and reflexivity in teacher candidates, as a key aspect of learning within the first semester of a teacher education program grounded in casebased collaborative inquiry. By sharing our own writing and narrative reconstructions inspired by "telling moments" in our teaching, we revealed and examined our own reflexive processes in relation to our seeking to nurture the same in our teacher candidates. In this way, we rendered visible "telling" tensions at the heart of our experiences, and depicted our evolving and shifting ways of making sense.

We were interested in understanding our experiences and learning from the first semester of our Secondary Teacher Education Program, which was an intensive, interdisciplinary, inquiry-based course that we were newly revising and actively co-constructing with colleagues. We crafted a three-day orientation, which introduced teacher candidates to the collaborative, inquiry-oriented nature of the course and contextualized its aims within the educational landscape. We did this through introducing students to overarching questions, engaging in community-building activities, taking up the work of 11 educational thinkers, and foregrounding the inextricable nature of the personal and the social in teaching and learning (Brookfield, 1995; Leggo, 2008b; Palmer, 2007). These aspects of the program were informed by our beliefs, readings, actions, and interactions-and the tensions that arose as we worked towards our explicit and implicit curricular goals. Over this term and the following year we used writing, conversation, and analysis of our narratives to deepen our understandings of how our identities and relationship to our practice-and one another-are continuously emergent and co-created. 


\section{Grounding Our Inquiry}

As researcher-practitioners, how we conceptualize our research and practice are continuously informing one another. Given that we understand practice as research and research as practice, here we engage with the thinkers with whom we invited our students to engage during the orientation and semester. For example, thinkers such as Meyer $(2008)$ and Brookfield $(1995,2006)$ helped us to explore reflective practice as we engaged teacher candidates in activities, readings, discussions, and dialogues related to teaching as lived inquiry (Meyer, 2008, 2010). Similarly, we introduced Brookfield's four lenses-autobiography, students, colleagues, and theory-as a framework to help teacher candidates appreciate the complexity and diversity of how teaching and learning can be perceived and enacted. This assisted us to de-center the authority of teacher and transmission-oriented pedagogy towards a more empathetic and responsive approach to being as a teacher. We drew from these same thinkers in terms of researching our experiences as sites of learning and knowledge.

For example, thinkers such as Archibald (2008), Cajete (1999), Miller (2007), and Leggo (2005) helped us to make space for diverse ways of knowing and learning through stories and emotion in order to trouble and extend our notions of education, teaching, and learning. Similarly, we used narrative, autobiography, and body/emotion to explore and surface our pedagogies and processes of identity development. Miller suggests that we challenge transmissive and transactional approaches to teaching in favor of more holistic and transformational pedagogies and conceptions. Leggo helped us attend to language and value our stories as sites of knowing and becoming. Archibald and Cajete offer us Indigenous perspectives of knowing and learning that emphasize how we must look within, find the roots of our experiences and share our stories, difficult as they may be, to locate what we value regarding education. This inquiry for us as teacher educators involved identifying and writing about our experiences, with the aim of sharing and learning together from our stories. Collaborative narrative inquiry is our professional development.

Our theoretical framework draws heavily on a socio-constructivist lens; meaning we understand relationship as the site of learning. Self-study researchers Berry and Loughran (2002) write, "accepting responsibility for, and genuinely caring about, the interpersonal relationships embedded in teaching is important in a pedagogy of teacher education, where there is a necessary synergy of learning between teacher educator and student teacher" (p. 27). Noddings (2002), Aoki (2005), and Kessler (2000) helped us to consider and explore relationality, presence, and the ethic of care as we worked to develop community and make sense of collaborative practice. The notion that we "co-author" identities (Nakkula \& Toshalis, 2006) with one another, our teacher 
candidates, and educational thinkers supported the theorizing of our professional development. Spanning this theoretical framework, our work with the teacher candidates, and our collaborative self-study, is an attempt to move from curriculum that ignores experience, emotion, and complexities of relationships in the service of efficiency and predetermined outcomes, towards an empathetic and responsive approach to being an educator.

Thus, we draw on these diverse educational theorists to help us articulate and make sense of our experiences within this relational pedagogical context. With our students, we make up overlapping communities of practice and inquiry within which we learn. To make sense of this ongoing interplay, we conceive our identities, learning, and knowledge as situated, relational, and constituted through shared actions, language, and social processes (Bakhtin, 1981; Lave \& Wenger, 1991; Varela, Thompson, \& Rosch, 1991). With this in mind, knowledge is a collective, embodied and situated activity. We cannot separate how we are coming to know from what we are coming to know. If we take as true that researching teacher learning and teacher education are similarly complex, we need to study and consider teacher educator professional development as such.

\section{Methodology}

Self-study scholarship (Hamilton \& Pinnegar, 1998; LaBoskey, 2004) focuses on the experiences of teacher educators and their learning. Across the literature pertaining to self-study, teacher educators engage in cycles of action and reflection through situated inquiry. Self-study uses a mix of qualitative methods that enable the researcher to develop a more complex portrait and analysis of their experience. For this study, we inquired into our assumptions about our teaching and learning and our roles as teacher educators through writing narratives. To support our writing process we ensured we were in a space conducive to meeting and sharing freely; developed a sense of hospitality for our meetings; and checked in with each other about other aspects of our work and lives to create personal connections. This also helped to create the safe container that we needed to become vulnerable enough to ourselves and to each other to write honest and authentic narratives of our personal professional experiences. In line with our socio-constructivist orientation, Berry (2004) reminds us that, "the 'self' in self-study encompasses a more diverse variety of selves than the teacher educator alone...collaborative conversations with the 'selves' who are colleagues may serve as the starting point for the study of teaching about teaching" (p. 1311). Noticing this intermingling of "selves" as we explored our experiences became an important element in how we saw themes emerging from our narratives and rendered more visible the complexity of our teaching and learning. 
Similarly, within the literature on teacher inquiry (Cochran-Smith \& Lytle, 2009; Jaworski, 2006; Nelson \& Slavit, 2008; Schnellert \& Butler, 2014), the roles of critical reflection and reflexivity appear as antidotes to cycles of inquiry where teachers do not challenge their assumptions. Teaching and learning are processes bound by historical and social practices, and we need to better "describe the history of the script set within which the teacher is busily improvising and performing" (Willinsky, 1989, p. 252) in order to better represent the systems and factors at play. In so doing, we might be able to move away from the common scripts of teaching and teacher education.

Pillow (2003) argues for a move away from comfortable uses of reflexivity to what she terms "uncomfortable reflexive practices" (p. 175), so that reflexivity is not taken up as a way to fix or reify oneself and others, or to find a transcendent "truth." She suggests, "practicing uncomfortable reflexivity interrupts uses of reflexivity as a methodological tool to get better data while forefronting the complexities of doing engaged qualitative research" (p. 175). Wolgemuth and Donohue's (2006) "inquiry of discomfort" has meaning here. They say, "the aim of an inquiry of discomfort is to identify and promote an intentional and conscious shift from dualistic, categorical, and entrenched positionality to a more ambiguous engagement with social reality" (p. 1024). We sought to develop our capacity to engage reflexively within our collaborative inquiry.

\section{Teacher Educator Inquiry Through Collaborative Writing}

Many have emphasized the significance and power of autobiographical writing in self-studies of educational practice (Chambers, Hesebe-Ludt, Leggo, \& Sinner, 2012; Cole \& Knowles, 2000; Mitchell, Weber, \& O'Reilly-Scanlon, 2005). We wrote and shared "telling moments" in our practice to understand what matters most to us and what meaning this held. We asked: what moments in our teaching "stopped" us? Writing on this simple question invariably opened pathways into intriguing, consternating, painful, and memorable stories from our recent experiences with teacher candidates and one another. By "storying" the emotional and felt sense of our experiences-by giving language and voice to what matters to us in this way-we surfaced and shared complexities inherent in embodying and enacting our commitments as teacher educators within a particular context. Speaking of the practice of life writing, Chambers and colleagues (2012) say that

individual pieces of creative non-fiction are based on the author's first person experiences of coming to understand what matters most to them (and others), what sustains them (and others) and the places they inhabit, and what they have given their hearts to. (p. $x x)$ 
In inquiring through writing, we illuminated the complexity of our relationships with ourselves, our teacher candidates, our colleagues, and how we relate to, remember, and experience pedagogic encounters. In inviting others to reflect on our pedagogic performance within the scripts and sets of our classroom (Willinsky, 1989), we gained new perspectives and explored tensions between what it means to perform our pedagogies versus what it means to co-author (Nakkula \& Toshalis, 2006) and experience our identities as emergent phenomena. Likewise, we wrote about these moments to support one another to learn through the challenges in our practice, and to build our capacity to respond and also relate to teacher candidates in more layered, nuanced, and emergent ways. We wanted to strengthen our capacity for shared risk-taking, vulnerability, and open-hearted connection as a foundation for our learning and our pedagogical process, recognizing that defensiveness, disengagement or anxious overperformance emerge when we feel isolated or threatened. By writing collaboratively we deepened our own teaching presence (Kessler, 2000) through the knowledge that we were not alone as we experienced the ups and downs and tensions of enacting our pedagogies, and tracked the ripples and reverberations which we call learning in a community of inquiry.

Engaging in writing as inquiry was both the method for exploring the experience of being a teacher educator, as well as an embodiment of our beliefs in teacher education as reflexive collaborative inquiry. Cole and Knowles (2000) address the autobiographical nature of teaching and the impossibility of separating knowledge from the knower. They propose that "when practice and practical action are recognized as an embodiment and expression of theory, teachers are, by extension, recognized as theory builders" (p. 9). Chambers et al. (2012) say that life writing can be understood "as a theorizing approach to educational inquiry and a method for it, a curricular and pedagogical practice" (p. xix). By collaboratively writing about our practices and responses, and reflexively engaging with our situation as co-authors rather than just as performers, we strengthened our capacity for coherent and integrated theory-building in relation to our program.

Our data consisted of retrospectively identified "telling moments." After the summer semester, we met six times to explore key experiences and interactions that had a lasting emotional impact. In this paper these "telling moments" were influenced by Applebaum (1995) and Fels and Belliveau's (2008) "stop moments" and Routman's notion of using "telling details" (2000) in stories. We spent the first 20-30 minutes of each meeting writing our telling moments. Then, we read our narratives out loud and responded to each other's writing —-sharing themes we heard, posing questions, adding our own recollections, and suggesting possible interpretations. 
This process allowed us to investigate tensions in our teaching (Berry, 2004) as we negotiated our practices in relation. This inquiry process is at the heart of how we have come to understand and engage in our professional development. It enabled us to ground, embody, and co-author our identities through critically reflexive methods. In the following section each of us "take up" a telling moment.

\section{Sabre's Telling Moment}

"What are ways that you soothe your own fears?" Pamela asked me after she heard me read my telling moment about my visit with Sean. This is my first experience of reflecting with colleagues about my practice, and certainly the first time that I've reflected in a group about what works-but also what worries me, scares me, and, after her prompt, about the ways that I soothe myself as I work through these insecurities as part of my ongoing learning as a university teacher. I'm nervous about sharing too much with my colleagues, and find myself wondering how I challenge myself to take the risk of being more authentic in my learning, a risk that I'm asking of my students.

Sean had come to see me to talk about difficulties that he was experiencing with his group. I sensed that there was more going on for him, and I decided to see if he wanted to talk about what was worrying him. After we talked a bit about his concerns with his group project, I shared, "I understand what you're saying, Sean, I sometimes have a hard time working as part of a group. Even if I really value collaborating, I sometimes get frustrated and angry with the process that doesn't always seem to be one that I can control." We talked some more about how we both have put a lot of our time and energy into competitive sports and that we sometimes wish that group work would happen the way practices do: with coaches giving the general play and the players working together to execute the play. We laughed about how sports don't always translate to real life and how the work in this program was different than what he'd expected. I confessed, "You know, Sean, I started this summer with some of the same worries as you, because I had never worked with a group of teachers to figure out our way together. We've been working together to develop and offer this course. It's been hard for me to give up my need to know how it'll work out and to go with the flow more as the learning emerges. It's been scary for me." We talked further and he seemed relieved to learn that, although he still felt worried about how to work with his group, others shared these same feelings. He left my office with a more relaxed smile. After he left, I remember wondering if I shared too much of myself with him.

As I recounted my moment with Leyton and Pamela, I experienced the same worry, namely: "Am I sharing too much of my personal thoughts and feelings with them?" There is comfort, for me, in hiding from the personal, even though that is what I value 
deeply as a teacher-engaging with students in a personally meaningful way. Pamela's prompt is uncomfortable for me, and it's also what I most crave in my work-chances for personal growth through my work in the community. What I am starting to notice as I engage in these writing and reflecting sessions with my partners is that I sometimes resist the opportunity to become fully present and open to who I am and who I may become as a teacher, even though I encourage students to tune in to their inner world as an essential part of their journey towards becoming teachers. Pamela's question reminds me to be as patient with myself as I am with my students, as I learn new ways of reflecting on and revealing my authenticity, first to myself and then to her and Leyton.

As a teacher educator, I aim to create a community where students feel safe to explore their inner lives_-both the light and the shadow sides (Palmer, 2007) - as part of the learning process of negotiating an emerging professional identity, and, also as a way to reflect on their role and influence in the interconnected relationships that make up our classrooms and communities (Starratt, 2005). Talking with Sean awakened me to his fears, worries, and insecurities. As I honored these feelings through listening and sharing with him, I was able to create a space for him to work his way toward greater understanding about himself. This quality of presence (Kessler, 2000) attained through listening awakened in me a sense of my own vulnerability and insecurities, and created the space for sharing these common emotions with a student. Palmer (2007) describes how,

(I)f we want to grow as teachers - we must do something alien to academic culture: we must talk to each other about our inner lives_risky stuff in a profession that fears the personal and seeks safety in the technical, the distant, the abstract. (p. x)

As I reflected with my colleagues about the challenges of integrating mind, heart, and body in the community at an institution that values individualistic pursuits of measurable outcomes (Palmer \& Zajonc, 2012), I noticed that the collaborative selfstudy offered me community for talking about the role of the inner life in my work, something that both challenged me and provided a safe space for me to uncover some of my own beliefs, desires, conflicts, and understandings.

\section{Pamela's Telling Moment}

Sidney was vibrating on the edge of her seat. Her twinkling eyes locked to mine.

"Maybe you would like to co-lead the next session, Sidney?"I smiled at her acknowledging that I could see her excitement even though she had not spoken up. 
"Yes!" She nodded rapidly.

The teacher candidates had suggested that they lead the next debrief session. Eric had already volunteered and now Sidney would be co-leading with him. Because the seminar debrief time was so valuable and I wanted it to go well, I did not want to give over control of it just yet. However, I wanted to support the group's desire to take it on and was pleased that Sidney, who was very quiet in the group, wanted to step forward. So, I agreed.

The next debrief session was not the easiest one to facilitate. It followed a student-run seminar that did not go particularly well, and an honest conversation was needed. Sidney and Eric had prepared a process for debriefing similar to what we usually did with a mix of written reflection, discussion, and questions. Instead of a lively conversation though, we progressed in a stilted and superficial manner for 20 minutes. The students who usually spoke up did not say much. Throughout, I watched and waited, working hard to not jump in and take back the facilitator role. Time moved slowly. People fidgeted. Sidney started to look discouraged. Eric had his usual cheerful face but I could tell he felt awkward.

Well, at least they can tell it's not going well, which is more than I can say about the students whose session was being debriefed.

Thom, who had led the seminar, expanded on why he had approached it in a transmissive lecture style. Michael who had also been part of the seminar group was offering only short comments, as was Megan. Rather than unpacking, questioning, and building on what had occurred in the struggling seminar, the debrief session was helping to reinforce their approach.

Roberta kept looking at me, but saying nothing. Was she thinking, "Do your job?" I wondered. I felt uneasy, but kept smiling back, urging her to speak up. Facilitation by telepathy?

"Sidney and Eric, do you mind if I offer something?" I finally asked. They looked as relieved as I felt that I was taking back control.

"So, what is happening here? What do you notice?" I queried.

I told the group how the conversation felt stilted to me, and offered that conversations feel stilted sometimes when something needs to be said but no one is saying it.

I had barely finished my sentence when Roberta dove in with intensity. It was the first 
counter-offering to the upbeat story that was being woven about the struggling seminar. More members started contributing. Some people spoke about how they had not understood the purpose of the seminar or what they were supposed to take from it. They were working to frame what they were saying in tactful, yet honest, terms. They validated risks that had been taken by the seminar leaders. Michael spoke up and said that as one of the seminar leaders the critique fit how he had felt, but had not been able to say so.

"We value being able to see what happens when we try something risky that does not quite succeed," someone said.

"That is what we are here for," said another.

There now was emotion flowing in the group.

"Thank you, everyone." I said. "We are having a tougher conversation than we had initially been having and you are all doing really well. Now... we just need to debrief our debrief session!" We all laughed.

"What was it like for you to facilitate?" I asked Sidney and Eric. "What did you notice? What did it feel like?"

"We prepared in advance," Sidney emphasized. "But despite this I was not sure what to do at times and how much to probe or question."

A few agreed that as the instructor, I should be the one doing this.

I felt a tinge of disappointment. Did they think I had abdicated? Why did I not follow my instincts?

At the end, someone offered that speaking truthfully was harder in some ways, but it felt like we were now closer as a group than before. As the group ended and students were collecting themselves and their belongings, James and I made eye contact. "Whew!" he said. "That was hard. But good."

At one of our first writing sessions, Leyton asked me "so, what is your pedagogy?" While this is a question I hope to never answer with finality, at the core will always be the desire to open to the "momentousness of each moment" (Leggo, 2008a, p. 168) and engage creatively in life and learning encounters. I am learning how dwelling with a diversity of perspectives on "what is" constitutes powerful teaching. This includes 
leaning gently into the quieter moments and sensing what is below the surface of a situation. I believe like Aoki (2005) that we need to

set aside these layers that press upon us and move to indwell in the earthy place where we experience daily life with our colleagues and teacher candidates, and begin our search for the "isness" of teaching, for the being of teaching. (p. 190)

So, I track moments as they occur and through simple questions invite students to build their capacity for awareness and share their perspectives. I ask: What is happening here? What does it feel like? What do you notice? This opening to diverse perspectives around a moment surfaces the authentic complexity of learning in community.

Poet Robert Bringhurst (2007) borrows the musical term "polyphony" (meaning many voices in co-existence) to describe this state: he maintains that polyphony is the natural order of things and that we need not create this state, but rather attend and become aware of it. This he says is "dancing in tune with being." Aoki (2005) says: "Let us beckon these voices to speak to us, particularly the silent ones, so that we may awaken to the truer sense of teaching that likely stirs within each of us" (p. 188). This capacity to attend to the diverse perspectives and voices within ourselves and within a group experience enables us to lean into-rather than shut down or shy away from-the complexity that dwells at the heart of teaching and learning. I seek to build community through this process of consciously co-constructed awareness of the "isness" of difference and diversity.

\section{Leyton's Telling Moment}

"Dr. Schnellert, can I talk to you?" Bailey tentatively sat down in my overstuffed office. "Thanks for The Art of Racing in the Rain. I got started on it" she shared.

"How was your weekend?" I asked.

"I'm starting to get used to the bus route-I've been here a week now-but I still can't figure out which way east and west are. I did more reading for the case and I really think that Liam needs some better friends. He is attaching to the wrong people," Bailey shared.

"Interesting insight, Bailey. Have you shared this with your group?"I hinted with my voice. When I received a concerned look back. I asked, "How is your group doing with the case?" 
Her eyebrows shot up. "Well..." she slowly intoned "there are definitely some strong voices. I'm a lot different, I like to think and write about my thoughts before I share them." She opened her Commonplace Book to a page filled with beautiful handwriting.

"Are you offering up these ideas?" I inquired.

"I have tried a couple times, but I am shy and get anxious when everyone looks at me, waiting. I just finished my History degree before coming to this program; we did not have this kind of group work!"

I pondered how to tackle this. Stan, Janice, Trina, China, and Mindy had already been in for conferences. Each had shared that they were frustrated with working as part of an eightperson case team. In his conference Stan self-identified as an introvert, which surprised me considering he spoke the most in group conversations. Trina, also new to town, had shared a "power of introverts" YouTube clip with the group, and thus far each member of this case team had worked into their conference with me that they were introverts and that group work was not a good match for their learning style. I found the group was testing my belief in collaborative inquiry. In planning this course I had advocated for case teams and assured my colleagues that after a couple days of guidance from us the groups would be functioning inquiry communities. Yet, my group appeared to be flailing and Bailey seemed truly frozen by the situation and how the group functioned. I kept up a brave front with the instructional team and teacher candidates, but each day during that first week I drove home with Pamela and confessed my doubts. On Friday I checked in with the group to offer tips.

"Like you suggested to us on Friday, I set a goal for myself. I have decided to speak up more and be heard," Bailey declared with a tentative confidence. "I am going to share my ideas. I have done a lot of reading and think we need to go back to the Stengle article."

Could Bailey make her voice heard? I managed to not offer more suggestions or direct her efforts.

Instead, I asked, "How can I help?"

"Nothing right now," said Bailey. "We all need to develop collaboration skills. This is going to be hard for me, but I have a goal and a plan." Determined, she headed out of my office.

Meeting to brainstorm, draft, share, and discuss my telling moments with Sabre and Pamela helped me to uncover the above moment, and also discover a key instance where my practice was responsive but also supported emergence. During the summer 
I worried constantly about how this case group struggled with collaboration. I had tried to solve the group dynamic issue, but then they became other-directed, deferring responsibility to me. Reflecting back on telling moments from the summer helped me to identify when and how I made space for Bailey to take ownership of her learning. This recollection sent me back to the teacher candidates' interview transcripts. Rereading the transcripts from Bailey and her case team members' interviews, I noted that each felt they had developed an appreciation for, and skills related to, collaboration during their turbulent summer. Bailey reported that she successfully drew from this experience in her practicum and sought out opportunities to co-plan, co-teach, and co-reflect with colleagues.

Taking the time to sit down, write, and share this moment helped me to recall that Bailey had set her own goals and how, in this instance, I had stopped offering suggestions and let her determine how she would address the challenge, making space for her to be a learning professional. Our collaborative self-study writing process helped me attend to and embrace moments where I balanced responsiveness and relationality with letting go of control within my teaching self. A teaching identity is under constant construction, deconstruction, and repair (Britzman, 2003). Rediscovering moments where I engaged students in co-constructing the curriculum and their practice drew my attention back to the relational and emergent aspects of knowledge construction (Ellsworth, 1997; Lather, 2001). Taking the time to identify and inquire into this "telling moment" helped me to reground myself in my commitment to creating spaces where teacher candidates can develop rich understandings and practices as collaborative colleagues.

The course we created required collaborative inquiry and critical reflection. Looking back, I realized that I was struggling to let the teacher candidates forge understandings and practices because I inserted myself into their group to "help" them solve their problem. Through self-study, my colleagues and the teacher candidates helped me to become more aware of the inevitable hierarchy and power relations I am privileged with as a teacher educator. Working with Sabre and Pamela helped me to step back and find a moment in my summer teaching where my actions and beliefs aligned. As a result, I have renewed my commitment to embracing and nurturing agency within teacher candidates, thus allowing them forge their teacher identities through collaboration and living inquiry. As educators we are proscribed within social, cultural, and political discourses from which we will never fully be free, but slowing down and inquiring into what this moment wanted to tell me regrounded me in the potential of deep listening, and also that of these learning professionals as authors of their own practice, learning, and identities. 


\section{What Did We Learn?}

Reflecting on our narratives, certain themes begin to emerge. We recognize the parallels between the needs and supports shared by teacher candidates and teacher educators. Seeking to control outcomes and manage the learning experience for self and others to mitigate against unfavorable impressions was a common theme. Sharing our stories made visible our efforts to enact the desires that guide our practice; for instance, we cultivated a space for emotion and intuition as part of learning for ourselves and for our students. Sharing our narratives helped us to become more conscious of how we value emotion and intuition in our pedagogies. We discovered that making space for emotion is foundational to our ability to collaborate and co-author. We found that paying attention to what arises in the moment in relation to our context, others, and ourselves underlies much of our learning. Finally, collaboratively deconstructing our work helped us to identify how we perform and negotiate power relations. We gained insight into how we are taking up, countering, and co-authoring new institutional narratives as part of the process of self-study. Through our collaborative writing and reflecting we can see how this catalyzed our learning and growth. Given this we have a new investment in, and willingness to pursue, collaboration in the future.

In being willing to reveal and relate through our more emotional and vulnerable selves - to show our light and shadow sides, dwell with unknowing and inarticulateness, dance more consciously with issues of power and control-we gain awareness of how our identities are forged through processing together these visceral encounters. Thus, we become more highly attuned to how our learning and development as teacher educators is held within and experienced through our particular co-constructed situations, our shared texts and narratives, and our willingness to give voice to our emergent perspectives. We need each other to point out those aspects that alone, are hard for us to notice. We also need each other for mutual support in accepting our imperfections. We also help each other debrief difficult situations where we are at risk of abandoning our pedagogy for efficiency and status quo expectations. We dwell in relational dimensions of teaching and learning in ways that are not typically recognized in the academy. "Stories present possibilities for understanding the complex, mysterious, even ineffable experiences that compose human living" (Chambers et al., 2012, p. xx). This work takes time. It exposes you. It is of the body and the emotional realms. It inverts hierarchies that place rationality as supreme and the messiness of emotion and relationship as less worthy.

Self-study is both a research and professional development method that makes space for teacher educators in the research-intensive academy to choose not to surrender teacher ways of knowing and theorizing (Hamilton, 2004). Collaborative narrative 
inquiry offers a way to locate, examine, and interpret tensions between philosophy and practice. Slowing down and paying attention to our "telling moments" helps us to see how collaborative writing and engaging with theory helps us learn and nurtures reflexivity. Through writing, reflecting on, and sharing aspects of our practice with teacher candidates and colleagues, we are revealing theory-practice dynamics for purposes of self-awareness and self-improvement. Finally, ongoing inquiry challenges ill-fitting aspects of self- and other-imposed expectations, restoring aspects of our identities that get undermined by external and internal forces. Through inquiry into our practice we can bridge the theoretical and pedagogical, which is what we expect of teacher candidates.

We are learning to attend to and embrace uncertainly and revisit and dwell in moments of tension, anxiety, and disruption. Doing this in community is both nourishing and challenging, as it helps us to acknowledge and learn from the complexity of our experiences. Reflexive inquiry helps us re-engage with significant educational thinkers and opens us to conversations (Cole \& Knowles, 2000). Reflexive practitioner inquiry is generative; we are becoming more responsive as we co-construct our pedagogy. Within nested communities of inquiry, we can ensure those facets of identity vital to the professional development of our teacher candidates, are likewise being nurtured within ourselves.

\section{References}

Aoki. T. (2005). Layered voices of teaching: The uncannily correct and the elusively true. In S. Pinar \& R. Irwin (Eds.), Curriculum in a new key: the collected works of Ted Aoki (pp. 185-197).

Appelbaum, D. (1995). The stop. Albany: State University of New York Press.

Archibald, J. (2008). Indigenous storywork: educating the heart, mind, body, and spirit. Vancouver, BC, Canada: UBC Press.

Bakhtin, M. M. (1981). The dialogic imagination: four essays. M. Holquist, Ed. (C. Emerson \& M. Holquist, Trans.). Texas: University of Texas Press.

Berry, A. (2004). Self study in teaching about teaching. In J.J. Loughran, M.L Hamilton, V.K. LaBoskey \& T. Russell (Eds.), International handbook of self-study of teaching and teacher education practices (pp. 1295-1332). Dordrecht The Netherlands: Springer.

Berry, A., \& Loughran, J.J. (2002). Developing an understanding of learning to teach in teacher education. In J. J. Loughran \& $T$. Russell (Eds.) Improving teacher education practices through self-study (pp. 13-29). London: RoutledgeFalmer.

Bringhurst, R. (2007). Everywhere being is dancing. Kentville, Canada: Gaspereau Press.

Britzman, D. (2003). Practice makes practice: A critical study of learning to teach (Rev. Ed.). Albany: State University of New York Press.

Brookfield, S.D. (1995). Becoming a critically reflective teacher. San Francisco: Jossey 
Brookfield, S.D. (2006). The skillful teacher: on technique, trust and responsiveness in the classroom. San Francisco: Jossey-Bass. Bass.

Cajete, G. (1999). Look to the mountain: An ecology of Indigenous education. Skyland, NC: Kivaki Press.

Chambers, C., Hesebe-Ludt, E., Leggo, C., \& Sinner, A. (2012). Life writing and literary métissage as an ethos for our times. New York: Peter Lang.

Cochran-Smith, M., \& Lytle, S.L. (2009). Inquiry as stance: practitioner research in the next generation. New York: Teachers College Press.

Cole, A. L., \& Knowles, J. G. (2000). Researching teaching: exploring teacher development through reflexive inquiry. Needham Heights, MA: Allyn \& Bacon.

Ellsworth, E. (1997). Teaching positions: Difference, pedagogy, and the power of address. New York: Teachers College Press.

Fels, L., \& Belliveau, G. (2008). Exploring curriculum: performative inquiry, role drama and learning. Vancouver, BC: Pacific Education Press.

Hamilton, M. (2004). Professional knowledge, teacher education and self-study. International Handbook of Self-Study of Teaching and Teacher Education Practices (pp. 375-419). Norwell, MA: Kluwer Academic Publishers.

Hamilton, M.L., \& Pinnegar, S. (1998). Reconceptualizing teaching practices: Selfstudy in teacher education. New York: Falmer Press.

Jaworski, B. (2006). Theory and practice in mathematics teaching development: Critical Inquiry as a mode of learning and teaching. Journal of Mathematics Teacher Education, 9, 187-211.

Kessler, R. (2000). The soul of education: helping students find connection, compassion, and character at school. Alexandria, VA: Association for Supervision and Curriculum Development.

LaBoskey, V.K. (2004). The methodology of selfstudy and its theoretical underpinnings. In J.J. Loughran, M.L Hamilton, V.K. LaBoskey, \& T. Russell (Eds.), International handbook of self-study of teaching and teacher education practices (pp. 817-869). Dordrecht, The Netherlands: Springer.

Lather, P. (2001). Validity as an incitement to discourse: Qualitative research and the crisis of legitimation. In V. Richardson (Ed.), Handbook of research on teaching (4th ed.). Washington, DC: American Educational Research Association.

Lave, J., \& Wenger, E. (1991). Situated learning: Legitimate peripheral participation. Cambridge, MA: Cambridge University Press.

Leggo, C. (2005). The heart of pedagogy: on poetic knowing and living. Teachers and teaching: theory and practice, Vol. 11, No. 5, 439-455.

Leggo, C. (2008a). Astonishing silence: Knowing in poetry. In A. L. Cole \& J. G. Knowles (Eds.), Handbook of the arts in qualitative social science research (pp. 165-174). Thousand Oaks: Sage Publications.

Leggo, C. (2008b). The ecology of personal and professional experience: A poet's view. In M. Cahnmann-Taylor \& R. Siegesmund (Eds.), Arts-based research in education: Foundations for practice (pp. 89-97). New York: Routledge.

Meyer, K. (2008). Teaching practices of living inquiry. Paper presented at the Canadian Social Sciences of Education Conference (CSSE), May 30-June 2, 2008, Vancouver, BC: University of British Columbia.

Meyer, K. (2010). Living inquiry: me, my self, and other. Journal of Curriculum Theorizing, 26(1), 85-96.

Miller, J. (2007). The holistic curriculum (2nd ed.). Toronto: University of Toronto Press.

Mitchell, C., Weber, S., \& O'Reilly-Scanlon, K. (2005). Just who do we think we are?: Methodologies for autobiography and self-studying teaching. New York: Routledge-Farmer.

Nakkula, M.J., \& Toshalis, E. (2006). Understanding youth: Adolescent development for educators. Boston: Harvard University Press.

Nelson, T.H., \& Slavit, D. (2008). Supported teacher collaborative inquiry. Teacher Education Quarterly, 35(1), 99-116. 
Noddings, N. (2002). The challenge to care: An alternative approach to education. New York: Teachers College Press.

Palmer, P. (2007). The courage to teach: Exploring the inner landscape of a teacher's life. (2nd ed.). San Francisco: Jossey-Bass.

Palmer, P., \& Zajonc, A. (2010). The heart of higher education: The call to renewal. Transforming the academy through collegial conversations. San Francisco: Jossey-Bass.

Pillow, W. (2003). Confession, catharsis, or cure? rethinking the uses of reflexivity as methodological power in qualitative research. Qualitative Studies in Education, 16(2), 175-196.

Routman, R. (2000). Conversations. Portsmouth, $\mathrm{NH}$ : Heinemann.

Schnellert, L., \& Butler, D.L. (2014). Collaborative inquiry: Empowering teachers in their professional development. Education Canada, 54(5), 42-44.
Starratt, R.J. (2005). Cultivating the moral character of learning and teaching: A neglected dimension of educational leadership. School Leadership and Management, 25(4), 399-411.

Varela, F. J., Thompson, E., \& Rosch, E. (1991). The embodied mind: Cognitive science and human experience. Cambridge, MA: MIT Press.

Willinsky, J. (1989). Getting personal and practical with personal practical knowledge. Curriculum Inquiry, 79(3), 247-264.

Wolgemuth, J.R., \& Donohue, R. (2006). Toward an inquiry of discomfort: guiding transformation in "emancipatory" narrative research. Qualitative Inquiry, 12(5), 1012-1021. 


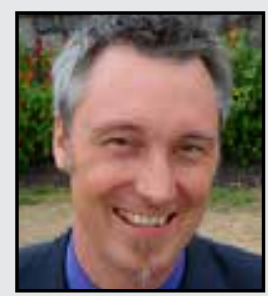

Leyton Schnellert has been a middle and secondary school classroom teacher and learning resource teacher for K-12. Leyton is an Assistant Professor in the Faculty of Education at The University of British Columbia - Okanagan. His teaching and research are in the areas of inclusive education, professional development, literacy, self-regulated learning, and rural education. Leyton has co-authored several books with and for educators including, Student Diversity, It's All About Thinking, and Pulling Together.

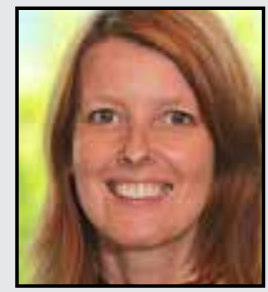

Pamela Richardson is an Instructor in the Faculty of Education at the University of British Columbia - Okanagan where she teaches courses in the areas of Special and Inclusive Education. Her research focus is on critical and post-structural approaches to understanding human development and exceptionality, and includes interpretive and arts-based methods. She completed a literary arts-based PhD in Special Education at the University of British Columbia in 2010.

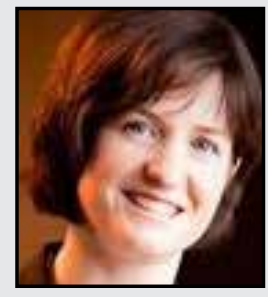

Sabre Cherkowski is an Assistant Professor in the Faculty of Education at University of British Columbia - Okanagan. She teaches and researches in the areas of educational leadership, teacher development, and diversity and education. She is currently researching organizational culture and climate from a positive perspective, with a focus on flourishing in schools. 